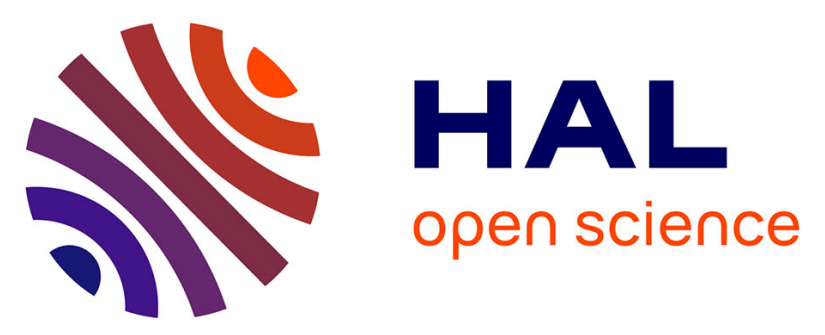

\title{
Trait-based sediment retention and runoff control by herbaceous vegetation in agricultural catchments. A review
}

Léa Kervroëdan, Romain Armand, Freddy Rey, Michel-Pierre Faucon

\section{- To cite this version:}

Léa Kervroëdan, Romain Armand, Freddy Rey, Michel-Pierre Faucon. Trait-based sediment retention and runoff control by herbaceous vegetation in agricultural catchments. A review. Land Degradation and Development, 2021, 32 (3), pp.1077-1089. 10.1002/ldr.3812 . hal-03240034

\section{HAL Id: hal-03240034 \\ https://hal.science/hal-03240034}

Submitted on 27 May 2021

HAL is a multi-disciplinary open access archive for the deposit and dissemination of scientific research documents, whether they are published or not. The documents may come from teaching and research institutions in France or abroad, or from public or private research centers.
L'archive ouverte pluridisciplinaire HAL, est destinée au dépôt et à la diffusion de documents scientifiques de niveau recherche, publiés ou non, émanant des établissements d'enseignement et de recherche français ou étrangers, des laboratoires publics ou privés. 


\section{ACCEPTED VERSION}

1 Trait-based sediment retention and runoff control by herbaceous vegetation in

2 agricultural catchments. A review

3

4 Léa Kervroëdan ${ }^{* 1,2}$, Romain Armand ${ }^{1}$, Freddy Rey ${ }^{3}$ and Michel-Pierre Faucon ${ }^{1}$

5

$6{ }^{1}$ AGHYLE (SFR Condorcet FR CNRS 3417), UniLaSalle, 19 rue Pierre Waguet, 60026

7 Beauvais, France

$8{ }^{2}$ AREAS, 2 avenue Foch, 76460 St Valéry en Caux, France

$9{ }^{3}$ Univ. Grenoble Alpes, INRAE, UR LESSEM, 2 rue de la Papeterie, BP 76, 38402 Saint

10 Martin-d'Hères cedex, France

11 *Corresponding author: lea.kervroedan@unilasalle.fr

14 Abstract

15 Soil degradation by concentrated runoff and soil erosion induces major environmental and 16 economic damages, notably in agricultural areas under temperate climates. The use of 17 herbaceous vegetation aims to increase the hydraulic resistance and thus reduce runoff and soil erosion while retaining sediments on site. However, the identification of the most suitable species to mitigate runoff is often specific to a phytogeographical territory and hampered by

20 the intraspecific variability, which reduces the transposition of a solution to other territories 21 and the ability to quantify the effects of the vegetation. Using a plant trait-based approach allows understanding and characterising the direct effects of the vegetation on runoff and soil erosion mitigation as well as on the sediment retention increase. Here, we review the influence

24 of plant aboveground functional types and traits of herbaceous vegetation on the hydraulic resistance and sediment retention and the contentious effects of the functional diversity on the 
hydraulic resistance and sediment retention, within agricultural catchments. Using this knowledge, we propose applications of the trait-based approach to design and manage herbaceous hedges for sediment retention and soil erosion control. This review synthesises recent advances regarding the effects of the functional traits on runoff and sediment retention and defines a trait-based selection method of the plant species for runoff and soil erosion control.

Keywords: Agroecological engineering; herbaceous hedges; hydraulic resistance; plant functional traits; plant-soil interactions; runoff-plant interactions.

\section{Introduction}

Soil erosion by water is a natural hazard frequently observed in tropical, Mediterranean and temperate areas leading to soil degradation, and is accentuated by anthropogenic factors, especially by agriculture (Poesen, 2018). The efficiency of herbaceous vegetation to mitigate soil erosion has been established for the past decades and their different effects on the soil erosion processes (Figure 1) have been intensively studied (Haan et al., 1994; Liu et al., 2020; Ludwig et al., 2005; Mekonnen et al., 2015). Herbaceous vegetation reduce soil erosion by protecting the soil against the raindrops impacts; furthering infiltration; stabilising soil; increasing surface roughness; reducing runoff velocity; boosting evapo-transpiration; and inducing sediment retention (Morgan, 2009; Styczen \& Morgan, 1995). However, the plants efficiency towards runoff and soil erosion reduction depends on the species used, which points to the importance of inter and intraspecific variations in plant traits (Cao et al., 2015; Hayes et $a l .$, 1984). The effects of plant root density, length density, tensile strength, area ratio and 
system morphology on soil and slope stabilisation as well as on soil shear strength have been thoroughly analysed (De Baets et al., 2006, 2009; Stokes, 2007; Stokes et al., 2014). The reduction of the splash-driven soil detachment due to the vegetation has also been well documented, showing the positive effect of the plant canopy on the decrease of the raindrop kinetic energy (Gyssels et al., 2005; Morgan, 2004; Styczen \& Morgan, 1995). The infiltration rate and the hydraulic resistance are the two main processes inducing sediment retention at the vegetation patch scale. As long as the hydraulic conductivity of the soil remains unsaturated, the soil infiltration rate, increased by the presence of the vegetation, slows the runoff generation (Styczen \& Morgan, 1995). However, once the soil reaches the saturated hydraulic conductivity, the main process inducing sediment retention and the reduction of the runoff flow velocity is the hydraulic resistance created by the vegetation (Styczen \& Morgan, 1995), which also furthers infiltration (Dabney et al., 1995; Dosskey et al., 2010; Gilley et al., 2000). The hydraulic resistance is the force that overland flow experiences on the soil surface and which may be influenced by the frictional drag-over the elements present at the soil surface scale such as residue cover, clods, gravel and standing vegetation (Gilley \& Kottwitz, 1995). Indeed, the aboveground biomass of the herbaceous vegetation slows the flow velocity down, creating a backwater area in front of the vegetation where sediments settle as the sediment transport capacity of the flow is reduced (Akram et al., 2014; Cantalice et al., 2015; Hussein et al., 2007). This plant effect can be modelled by the use of hydraulic roughness coefficients, such as DarcyWeisbach $\mathrm{f}$ and the Manning's $\mathrm{n}$ (Haan et al., 1994). Most of the studies referencing the reduction of soil erosion by plants focussed on semi-arid and Mediterranean climates, as higher soil erosion rates are found in these areas (De Baets et al., 2009; Durán Zuazo \& Rodríguez Pleguezuelo, 2008; Liu et al., 2020; Vannoppen et al., 2015; Zhu et al., 2015), giving soil erosion processes under temperate climates less importance, mainly due to the average slope gradients lower than 5\% (Remy \& Le Bissonnais, 1998). 


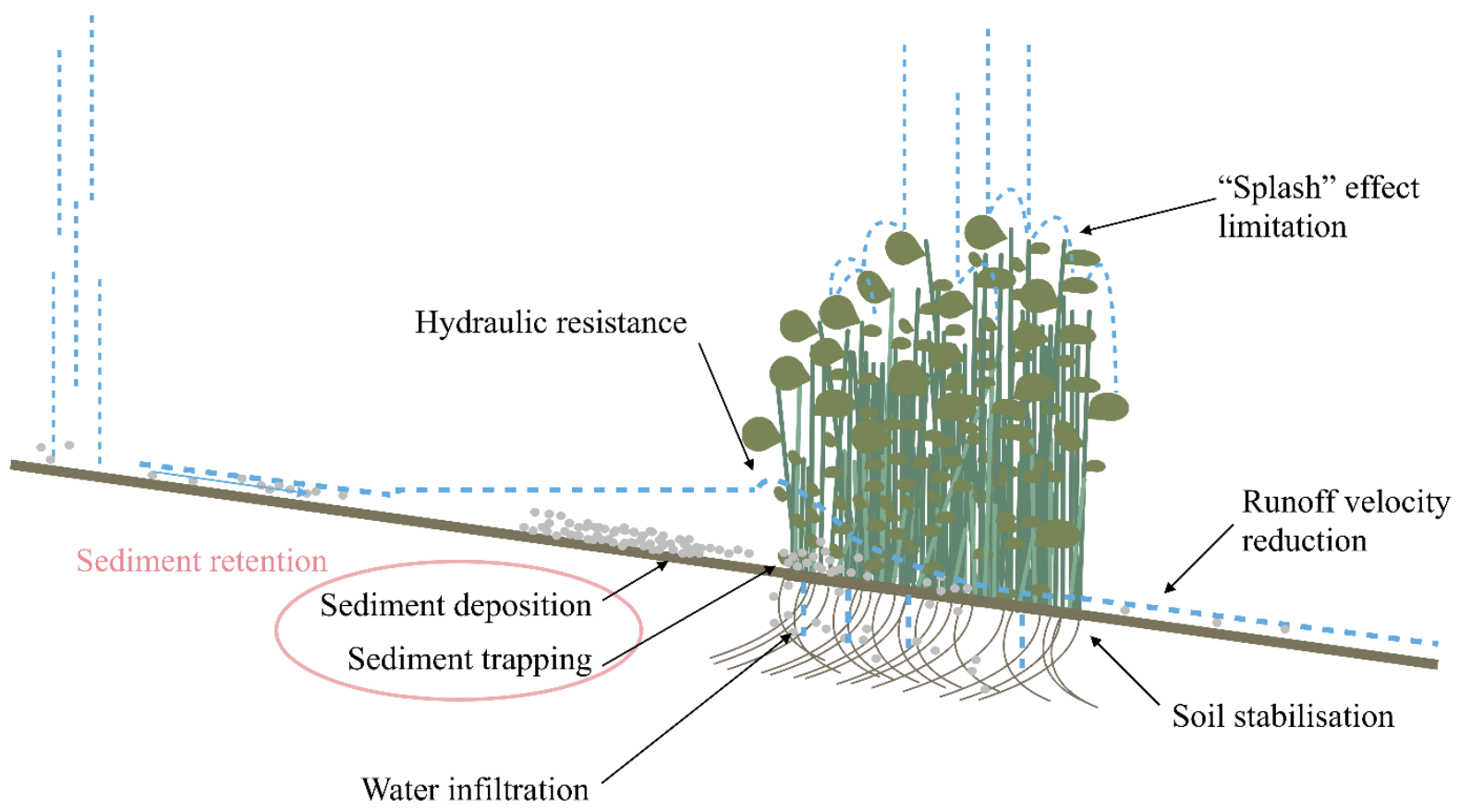

Figure 1. Effects of herbaceous vegetation on soil erosion processes

The reduction of the runoff flow velocity and soil erosion rates is mainly induced by the hydraulic resistance of the plants at the vegetation patch scale in temperate agricultural catchments. Distinctive to temperate oceanic climates, these catchments are regularly affected by intense runoff and soil erosion episodes, due to the intensified tillage and the cultivation of annual crops on sloping loamy soils (Boardman \& Poesen, 2006; Gobin et al., 2003; Styczen $\&$ Morgan, 1995). The improvement of the herbaceous vegetation efficiency for the mitigation of soil erosion requires a good understanding of the relationship between the plant aboveground functional traits and the hydraulic resistance. Functional traits are defined as "morpho-physiophenological traits which indirectly impact fitness via their effects on growth, reproduction and survival" (Violle et al., 2007). Trait-based ecology and agroecology allow characterising the plant responses to environmental changes and their effects on ecosystem processes, such as

90 soil erosion, and allow the transposition of these effects to other biogeographical territories

91 (Burylo et al., 2012; Kervroëdan et al., 2018; Liu et al., 2018b). Studying the linkages between the plant functional traits and the soil properties and processes constitutes an essential approach 
93 to understand hydrological processes allowing to design new ecosystems offering the best

94 efficiency for the reduction of soil erosion (Faucon et al., 2017). The functional diversity, defined as "the value, range, and relative abundance of plant functional traits in a given ecosystem" (Díaz et al., 2007a; Tilman, 2001), influences the ecosystem processes and

97 functioning, although its effects are contentious (Garnier et al., 2016). The "mass ratio hypothesis" stipulates that the ecosystem properties are driven by the traits of the dominant species in the community (Grime, 1998). Accordingly, the ecosystem properties would be determined by the community-weighted mean trait values of the dominant species (Díaz et al., 2007b). On the other hand, the ecosystem processes can also be driven by non-additive effects (i.e. complementarity or facilitation) among the coexisting species with diverse trait values, which can be designated by functional diversity indices (e.g. functional divergence, distance between high abundant species and the centre of the functional space) (Díaz et al., 2007b; Garnier \& Navas, 2012; Mouillot et al., 2011). Given that functional diversity impacts various ecological processes and notably soil erosion (Erktan et al., 2013; Garnier et al., 2016; Zhu et

$107 a l ., 2015)$, the effects of the plant functional diversity can be analysed to understand the 108 potential impacts on the hydraulic resistance and the resulting sediment retention.

109 Even though a number of studies have reviewed the effects of vegetation on the soil erosion

110 processes, linking plants with the overall soil erosion rates and soil loss, only a limited 111 specification of the plant traits influencing more targeted processes, such as sediment retention, 112 have been reported (Gyssels et al., 2005; Liu et al., 2018; Puigdefábregas, 2005). Identifying

113 the efficient functional traits to reduce concentrated runoff and soil erosion would allow 114 selecting plant species and designing herbaceous infrastructures to go further into land planning 115 and soil protection. This review synthesises the recent advances and contemporary 116 understanding on the effects of the plant functional traits in herbaceous vegetation on runoff 117 mitigation, sediment retention and soil erosion control in agricultural catchments by reviewing: 
118 (1) the influence of plant aboveground functional types and traits on the hydraulic resistance

119 and sediment retention; (2) the contentious effects of the functional diversity on the hydraulic

120 resistance and sediment retention and (3) the applications of the trait-based approach for the

121 design and the management of herbaceous hedges for sediment retention and erosion control.

2. Effects of plant aboveground functional types and traits on the hydraulic resistance and sediment retention

The characterisation of the functional types influencing the hydraulic resistance is required to identify the most relevant herbaceous vegetation (Figure 2A). Species favouring vegetative spreading with rhizomes, tilers or stolon can play a key role in the increase of the hydraulic resistance and sediment retention. Indeed, rhizomes and stolon guarantee a lateral spreading

130 growth pattern, with a dense and homogenous ground cover (100\%) limiting the presence of preferential flow paths within the vegetation, and a burying tolerance towards recurring sedimentation (Maun, 1998). The perennial herbaceous species under the Raunkiaer's life-form categories "herbaceous chamaephytes" and "hemicryptophytes" provide an effective soil cover

134 through all seasons by increasing the hydraulic resistance in comparison to bare soils (Bautista et al., 2007; Berendse et al., 2015; Martin et al., 2010). Within these life-form categories, the caespitose and non-caespitose types with fresh or dry biomass in winter allow a constant ground cover when soil erosion is observed at its highest in cultivated areas under temperate climates (Boardman \& Poesen, 2006; Durán Zuazo \& Rodríguez Pleguezuelo, 2008). The

139 herbaceous vegetation should present a higher vegetative height than the water maximal level

140 found in the targeted areas of implantation (e.g. $20 \mathrm{~cm}$ in north-west Europe at a frequency of 1415 to 10 years in a catchment of 20ha (Richet et al., 2017)) to be efficient against concentrated 142 flows (Dillaha et al., 1989; Van Dijk et al., 1996). Water maximal level should be estimated 
143 using the discharges of the erosional episodes against which the herbaceous vegetation should

144 be efficient. The functional types involved in the increase of the hydraulic resistance and

145 sediment retention could constitute a set of criteria to select potential candidate species within

146 a specific phyto-geographical area for soil erosion control (Figure 2A). Perspective is to define

147 the selection method and to integrate the effects of functional traits into the selection process

148 to design efficient herbaceous vegetation to mitigate soil erosion.

\section{PHYTOGEOGRAPHICAL TERRITORY SPECIES}

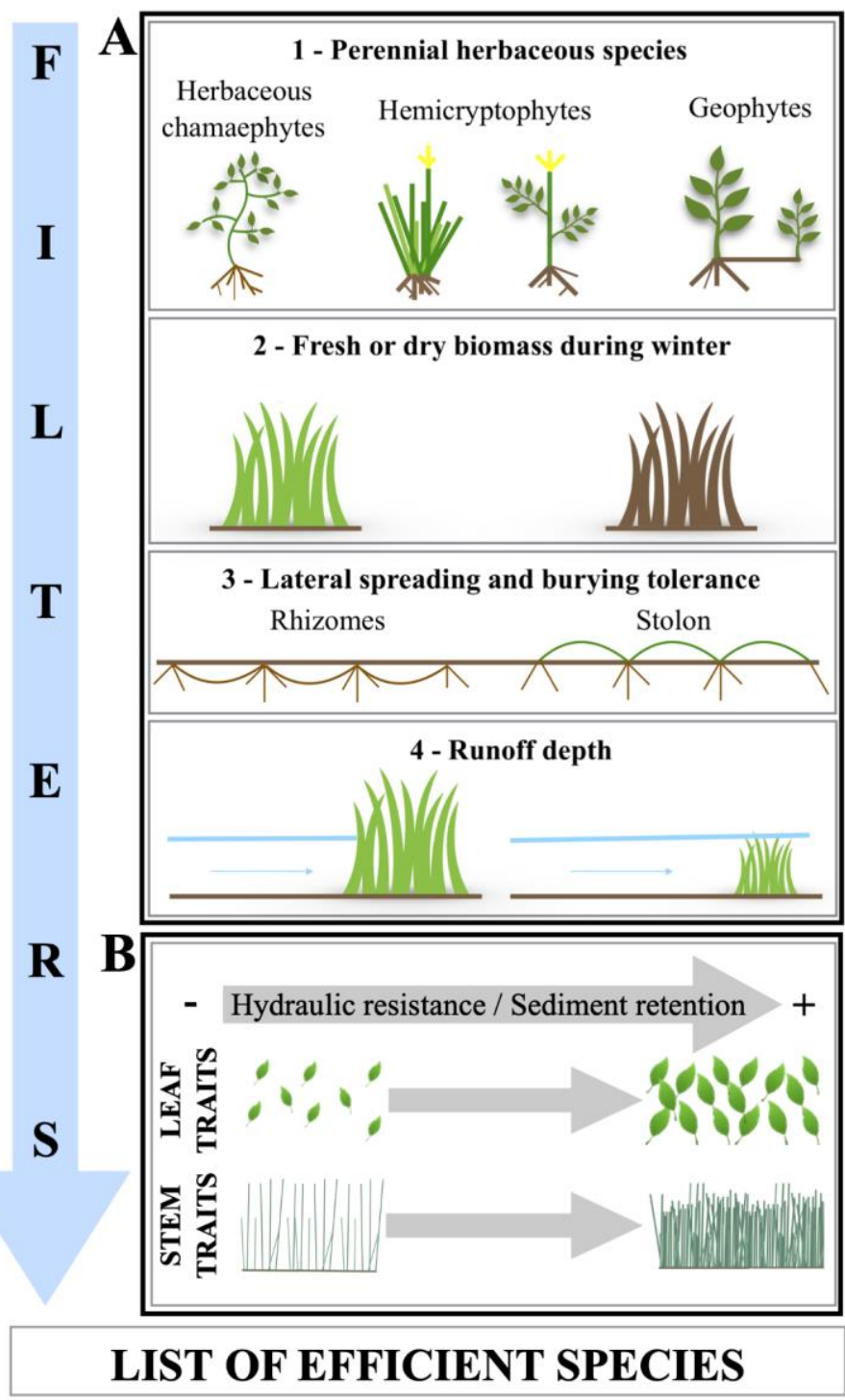

Figure 2. Functional types (a) and traits (b) involved in theincrease of the hydraulic resistance and sediment retention under temperate climates to select efficient herbaceous vegetation 
153 Most of the studies about the effects of vegetation on soil erosion and sediment retention focus

154 on the impacts of the aboveground functional traits. Both stem and leaf traits have been 155 identified for the past decades as efficient for triggering sediment retention (Figure 2B). The 156 leaf density and area are the main leaf traits impacting sediment retention (Burylo et al., 2012;

157 Graff et al., 2005; Lambrechts et al., 2014) and the hydraulic resistance (Kervroëdan et al., 158 2018). The stem density and diameter are two of the main stem traits influencing sediment 159 retention (Bochet et al., 2000; Isselin-Nondedeu \& Bédécarrats, 2007; Mekonnen et al., 2016; 160 Meyer et al., 1995; Morgan \& Duzant, 2008). The efficiency of the stem density on runoff 161 depends on the slope and the type of soil. Indeed, on $20 \%$ slopes of silty soils, vegetation with 162 a stem density of 7500 stems.m ${ }^{-2}$ would reduce the flow velocity by $90.6 \%$, while on a $10 \%$ 163 slope 2500 stems. $\mathrm{m}^{-2}$ would reduce the velocity by $91.9 \%$, in comparison to bare soil (Morgan, 164 2004). Focussing on the effects of traits on the hydraulic resistance at the vegetation scale in north-west Europe, Kervroëdan et al. (2018) investigated the effects of density-weighted traits (trait weighted by the density of the trait). This approach identified the most efficient combinations of density-weighted traits as: (1) the density-weighted leaf area (i.e. leaf area $\mathrm{x}$ 168 leaf density, in $\mathrm{mm}^{2} . \mathrm{dm}^{-2}$ ) with the density-weighted stem diameter (i.e. stem diameter x stem 169 density, in mm. $\mathrm{dm}^{-2}$ ) and (2) the density-weighted leaf area with the density-weighted 170 projected stem area (which represents the projected area towards the flow; stem projected area $\mathrm{x}$ stem density, in $\mathrm{mm}^{2} \cdot \mathrm{dm}^{-2}$ ), also emphasising the indirect effect of the stem density. The stem stiffness has also been found to induce sediment retention (Meyer et al., 1995), although 173 contrasting results are found in the literature (Burylo et al., 2012). These contrasting results 174 could be explained by the differences in the discharges used: with higher discharges (from 11 175 to $\left.43.71 . \mathrm{s}^{-1} \cdot \mathrm{m}^{-1}\right)$ an effect of the stem stiffness was found compared to smaller discharges (1.6 $\left.1 . \mathrm{s}^{-1} \cdot \mathrm{m}^{-1}\right)$; indicating that the effects of traits could change depending on the discharge. Indeed, 
177 the leaf area was found efficient for small discharges (2 and $\left.4 \mathrm{~L} \cdot \mathrm{s}^{-1} \cdot \mathrm{m}^{-1}\right)$ while the leaf density 178 only had an effect at higher discharges (8 and $\left.11 \mathrm{~L}^{-1}{ }^{-1} \cdot \mathrm{m}^{-1}\right)$ (Burylo et al., 2012; Kervroëdan et $a l ., 2018)$. A changing response of the leaf structure, stem density and diameter on the hydraulic

180 resistance and sediment retention was also found depending on the discharge used. At low 181 discharges, the hydraulic resistance was dependent on the vegetation density (Temple et al., 182 1987; Van Dijk et al., 1996); while at higher discharges, with flow depths higher than the 183 deflecting vegetation height, the hydraulic resistance was found primarily influenced by the 184 stem density, diameter and stiffness, and less by the leaf structure (Meyer et al., 1995; Temple 185 et al., 1987; Vieira \& Dabney, 2012).

186 The knowledge of the effects of plant traits on runoff and sediment retention constitutes an 187 advancement for the modelling of the vegetation effects on soil erosion and runoff mitigation, such as in VFSMOD (Vegetative Filter Strip Modelling System). This model evaluates the effects of vegetation on hydrology and sediment transport processes through vegetative filter strips. The model is physically based and simulates the sediment retention resulting of the

191 vegetation hydraulic resistance (e.g. Manning index). Although this model is widely used, the 192 characterisation of the hydraulic resistance of the vegetation is based on a limited number of 193 plant traits: stem density and height (Muñoz Carpena \& Parsons, 2014). Adding traits identified as efficient in increasing the hydraulic resistance in herbaceous hedges would extend the precision of the modelling of the efficiency of vegetative barriers and would broaden the field

196 of application of the model. Therefore, improvements may apply to: (1) the estimation of the

197 sediment transport and retention capacities, (2) the application of the model for other vegetative objects than vegetative filter strips and (3) the design of herbaceous vegetation by creating efficient vegetation for the hydraulic processes encountered in the implantation landscape.

200 Perspective is to compare results obtained using the model with ones obtained by 
experimentations and to identify the main traits increasing the hydraulic resistance and sediment retention.

2.3.Contentious effects of the functional diversity in herbaceous vegetation on the hydraulic resistance and sediment retention

207 For decades, studies highly focused on the effects of the functional diversity on few main ecosystem processes, notably related to the carbon cycles (Cadotte, 2017; Garnier et al., 2004; Zuo et al., 2016), but the effects of the functional diversity for a same process are found 210 contrasting (Faucon et al., 2017; Garnier et al., 2016; Mariotte et al., 2017). These contentious results stress the need to widen the range of processes related to plant-soil interactions which could be affected by the functional diversity.

213 Regarding runoff and soil erosion processes, most of the studies used a taxonomical 214 characterisation of the communities to analyse the effects of plant diversity (Bautista et al., 215 2007; Berendse et al., 2015; Fullen, 1998; Hou et al., 2016; Martin et al., 2010; Meyer et al., 216 1995; Pohl et al., 2009; Turnbull et al., 2008; Zhang et al., 2015). A number of these studies 217 focussed on the effects of non-herbaceous plant roots on soil stabilisation and vegetation patch 218 pattern impact on erosion rates, showing that an increase of diversity led to a better soil resistance and stabilisation (Balvanera et al., 2006; Gyssels et al., 2005), as well as an increase 220 of sediment retention in heterogeneous vegetation patterns (Hou et al., 2016). Other studies 221 focused on the effects of functional groups, marking a first step into the use of a functional characterisation of the vegetation effects on runoff and soil erosion processes. The results showed complementarity effects on runoff, soil erosion and soil aggregation capacity (Martin et al., 2010; Pohl et al., 2009; Zhang et al., 2015). However, using functional diversity - by taking into account the aspects of diversity that impact the community structure and functions 
- was highlighted to be a better predictor to characterise the effects of plant diversity on ecosystem processes (Cadotte et al., 2011), such as runoff and soil erosion.

Land restoration using monospecific vegetation may be inefficient in reducing soil erosion given their simple canopy (Cao, 2011; Cao et al., 2009), however the effects of functional diversity on runoff and soil erosion processes have not been thoroughly studied. It is hypothesised that vegetation with high species and functional diversity positively influence the hydraulic resistance and reduce soil erosion. Plants with wider stem diameters would support the stems and leaves of species with higher leaf area and density. The biomass productivity of herbaceous vegetation positively influences the hydraulic resistance and sediment retention (Burylo et al., 2012; Podwojewski et al., 2011). Positive effects of the functional diversity on plant productivity would thus lead to an increase of the hydraulic resistance and sediment retention. These positive effects could notably come from the belowground traits by inducing a diversification in the nutrients and water sources accessibility and acquisition in the soil profile (Faucon et al., 2017; Tilman et al., 2014). Only few studies have focussed on the

240 functional diversity effects on soil erosion at the ecosystem level, with controversial results

241 (Erktan et al., 2013; Kervroëdan et al., 2019; Zhu et al., 2015). In semi-arid grasslands, the functional divergence explained up to $40 \%$ of the variation of the erosion rates, due to a greater niche differentiation within the tested communities (Zhu et al. 2015). However, when focusing on the effects of functional types mixtures in Mediterranean mountainous ecosystems, no effect of the functional diversity on sediment retention was found, due to areas of least resistance to

246 flow created by the shrubs and trees individuals (Erktan et al., 2013). These results are consistent with other observed on the effect of trait divergence on the hydraulic resistance and sediment retention for herbaceous vegetation in a temperate agricultural catchment (Kervroëdan et al., 2019). However, the number of studies is limited to fully understand the effects of functional diversity on the hydraulic resistance and sediment retention. Perspective 
is to study a number of combinations of species and a wide gradient of functional diversity comprising traits involved in the hydraulic resistance and sediment retention increase. This would allow analysing the contentious findings and identifying if they could be the result of idiosyncratic effects of the traits, corresponding to contrasting effects of the functional diversity influenced by the species-traits and the plant-soil interactions.

\section{Applications to design and manage herbaceous hedges for sediment retention and} soil erosion control

In agricultural areas, implanting vegetative barriers in the form of herbaceous hedges across the flow path would reduce sheet and concentrated erosion, as well as retaining sediment (Dabney et al., 1995). Herbaceous hedges are narrow strips of dense and stiff perennial vegetation and present a high efficiency in reducing soil erosion caused by concentrated flows and for sediment retention (Dabney et al., 1995; Yuan et al., 2009). They have been used for decades in various areas such as in the United States, tropical or semi-arid areas (Dabney et al., 1995; Gilley et al., 2000; Liu et al., 2018; Mekonnen et al., 2016; Meyer et al., 1995; Wu et al., 2010; Xiao et al., 2012). They are differentiated from vegetative filter strips by their width and functions (Figure 3). While herbaceous hedges are specifically designed to further the hydraulic resistance and sediment retention in concentrated flow paths, vegetative filter strips further the water infiltration and sediment retention within a wide area ( $>5 \mathrm{~m}$ width) under superficial and

271 shallow flows and are useless under concentrated runoff events (Dabney et al., 1995; Dillaha 272 et al., 1989). 

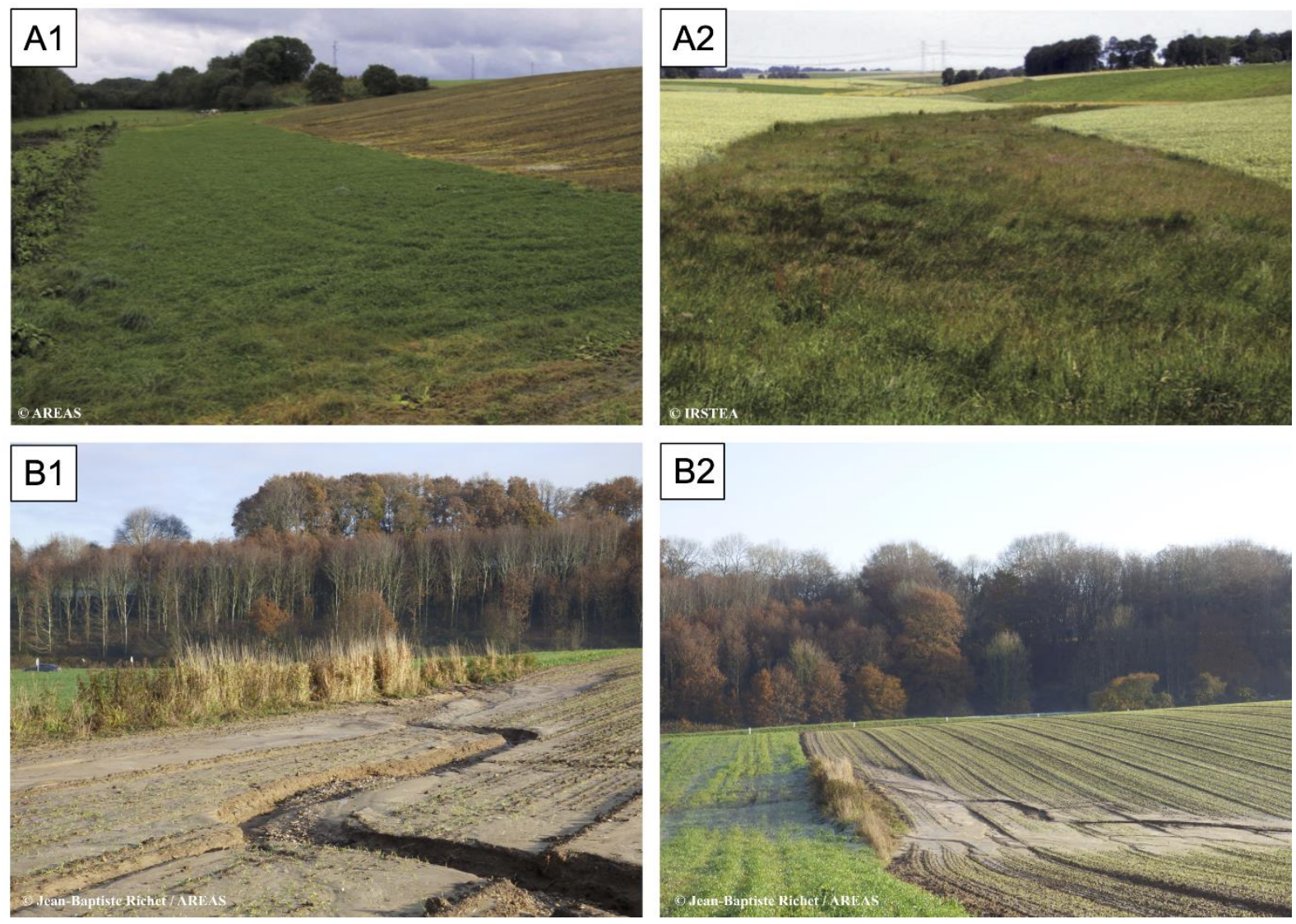

274 Figure 3. Comparison between vegetative filter strips (a) along: 1 - the thalweg's bottom line and 2 -an agricultural field; and a multi-specific herbaceous hedge (b) between two fields across a concentrated flow (1 and 2) west Europe

280 The first challenge is to apply defined criteria to select the species composition of herbaceous

281 hedges in different phyto-geographical territories. Focussing on north-west Europe, composed 282 of 3,500 spermatophyte species (Lambinon et al., 2012), with the following criteria based from 283 the functional types: (1) perennial herbaceous vegetation "herbaceous chamaephytes" and 284 "hemicryptophytes" which present biomass in winter (fresh or dry biomass) when soil erosion 285 is observed at its highest in north-west Europe (Boardman \& Poesen, 2006); (2) the presence 286 of rhizomes or stolon; (3) a minimum vegetative height equal or higher than $20 \mathrm{~cm}$, as it is the 
maximal level of the water flows in the north-west European catchments; (4) a broad ecological niche for an implantation in a wide range of silty agricultural soils; and (5) non-weed species to avoid the spreading of the vegetation into the agricultural fields; only 76 candidate species potentially able to mitigate runoff and soil erosion are highlighted (Table 1; Villarroel, 2015).

291 The characterisation of the effects of leaf and stem traits on the hydraulic resistance and sediment retention should be integrated into the selection criteria to narrow the list to efficient species, using the range of efficiency of the trait values. The threshold values of traits from which plants would efficiently increase the hydraulic resistance and sediment retention were identified using the unit stream power critical value of $0.004 \mathrm{~m} \cdot \mathrm{s}^{-1}$ (Govers, 1990), being the identified value of unit stream power from which the soil is likely to erode (for bare loess soils ( $\mathrm{D}_{50}$ from $58 \mu \mathrm{m}$ to $218 \mu \mathrm{m}$ ), with slopes ranging from $1^{\circ}$ to $8^{\circ}$ for discharges between 2 and $100 \mathrm{~cm}^{3} \cdot \mathrm{cm}^{-1} \cdot \mathrm{s}^{-1}\left(0.2\right.$ to $\left.\left.101 . \mathrm{s}^{-1} \cdot \mathrm{m}^{-1}\right)\right)$. These data were extracted from data in Kervroëdan et al. (2018), as it focussed on the effects of traits on the hydraulic resistance in agricultural catchments from north-west Europe (Table 2). By using both the efficient combinations and the identified threshold values, the 76-species list of potential candidate species could be narrowed down to the most interesting ones to create herbaceous hedges in north-west Europe. Perspective is to select the candidate species for north-west Europe and other phytogeographical territories regarding their stem and leaf traits using studies identifying the minimal threshold values of traits for the processes occurring in different phytogeographical territories. Trait databases could also be used to select the candidate species and could be completed, as there are many traits of interest for runoff and soil erosion mitigation that are lacking for many species. 
311 Biodiversity usually corresponds to a more ecologically stable system, as a stable and healthy

312 system would be less vulnerable to abiotic and biotic stress (Tilman, 1999). Therefore,

313 practitioners may ask if it is better to use only one or a few species that can efficiently increase

314 sediment retention and mitigate runoff and soil erosion, or if a diverse range of species,

315 sometimes less efficient, should be used. Most of the studied herbaceous hedges through the

316 literature were monospecific hedges (Cao et al., 2015; Cullum et al., 2007; Dabney et al., 2004;

317 Huang et al., 2010; Hussein et al., 2007; Lin et al., 2009; Liu et al., 2018; Mekonnen et al.,

318 2016; Meyer et al., 1995). However, the use of multi-specific vegetation to control runoff and

319 soil erosion has been studied (Bautista et al., 2007; Berendse et al., 2015; Erktan et al., 2013;

320 Hou et al., 2016; Kervroëdan et al., 2019; Martin et al., 2010; Pohl et al., 2009; Turnbull et al.,

321 2008; Zhang et al., 2015; Zhu et al., 2015), but some of the studies focussed on the diversity

322 of different functional types or within vegetation patches. A positive effect of plant diversity was also found on the soil erosion resistance (Berendse et al., 2015). Trait divergence showed positive effects on sediment retention and the hydraulic resistance in herbaceous vegetation in loamy agricultural catchments, although the efficiency of the multi-specific vegetation could be lowered by the presence of species with large stem (Kervroëdan et al., 2019).

Taking into account these contentious results and that species diversity within herbaceous hedges did not show negative interactions with the efficiency of the multi-specific hedges, it can be suggested using only few species with the best traits involved in decreasing runoff,

330 increasing sediment retention and mitigating soil erosion in a same herbaceous hedge (Rey \&

331 Labonne, 2015). However, species diversity should be favoured as much as possible to:

332 (1) enable reducing the risks of failure of vegetation systems in the case of the loss of a species on a site due to abiotic/biotic factors ((Berendse et al., 2015; Doak et al., 1998), and (2) provide

334 other ecosystem services (e.g. habitat creation, ecological connectivity enhancement, 335 integrated pest control). 

sediment retention and erosion control

Once the herbaceous hedges are designed and implanted, definition of their management plan

340 is essential to maintain or improve their efficiency on the hydraulic resistance, sediment

341 retention and erosion control. To do so, it is necessary to preserve the initial vegetation

342 structure, which has the best community-weighted traits involved in the increase of the

343 hydraulic resistance for processes in north-west Europe (i.e. leaf area and density, density-

344 weighted leaf area, stem projected area and stem diameter), by slowing down the vegetation

345 succession and, notably, shrub and tree colonisation. The establishment of scattered trees or

346 shrubs into the herbaceous hedge would enhance its infiltration capacity (Christen and

347 Dalgaard 2013), as long as they are kept at a low height and present a light foliage to avoid 348 competition and the reduction of the development of herbaceous species. The presence of too 349 many ligneous species would limit the development of the herbaceous species by competing 350 for the light and would then lead to the degradation of the herbaceous vegetation and thus, limit 351 the effects on the hydraulic resistance and sediment retention. Cutting the vegetation is recommended in order to limit the dominance of tree and shrub species over herbaceous species within the hedge. Cutting the hedge should be performed every two/three years at the end of spring (circa end of June) in order to (1) allow the plants to grow back before the highest erosion events in winter and (2) limit the damages on the local fauna which use the herbaceous hedges to nest. The first $10 \mathrm{~cm}$ should be left as a cover to ensure a minimum survival of the plant in case an erosive event happens before the regrowth of the plants. Perspective is to test these management practices regarding the durability of the herbaceous hedge and its efficiency towards sediment retention. 

hedges using a trait-based approach

363 Numerous soil and landscape processes can control runoff sources and pathways, which results in a spatially heterogeneous runoff and erosion distribution (Vandaele \& Poesen, 1995).

Sediment control is site specific and thus requires specific studies to target the efficiency of the herbaceous hedges (Mekonnen et al., 2015; Tomer et al., 2008). The first criteria to take into account when designing herbaceous hedges is setting the expected levels of impacts, regarding the rainfall properties and the reduction of suspended sediments. As the effects of the functional traits can change regarding the flow characteristics (i.e. discharges), it is important to implement the desired efficiency range of the hedge depending on the flow discharges into its design (Kervroëdan et al., 2018). For recurrent processes (from twice to once a year), the vegetation composing the hedge should comprise dense stems with large diameters, as well as large leaf areas. For more stronger processes occurring less regularly (from once every two to five years), vegetation with dense leaves and stems, important leaf areas and large stem diameters should be considered for the design of herbaceous hedges. The following factors should also be taken into account for design and modelling purposes (Carluer et al., 2017; Dosskey et al., 2015): (1) the specific catchment area (i.e. upslope area contributing to runoff generation); (2) the soil characteristics (e.g. texture); (3) the slope gradient and topographical features (e.g. thalwegs); (4) the crops and (5) the observed runoff pathways. These factors can be implemented in a scoping tool to help local planners to set-up the herbaceous hedges at the most efficient location (Carluer et al., 2017; Dosskey et al., 2011, 2015; Tomer et al., 2008).

382 These tools often rely on modelling soil erosion and runoff pathways using field scale (e.g.

383 VFSMOD, CREAMS, TRAVA, WEPP) or catchment scale (e.g. LISEM, GeoWEPP, SWAT) 384 models (Arnold et al., 2012; de Roo et al., 1998; Deletic, 2001; Flanagan et al., 2001; Knisel 
the location of vegetated objects such as filter strips have been developed (Gumiere et al.,

387 2011); however, herbaceous hedges functioning differently than filter strips, characterising a

388 protocol to locate suitable areas for herbaceous hedges is needed.

389 Two main approaches can be used to find out relevant location of herbaceous hedges (Dosskey

390 et al., 2011). The first approach assesses the capability of vegetated areas to reduce runoff and sediment transport through infiltration and sediment retention processes. This means using soil and slopes properties to determine the infiltration capacity of the vegetated area which allows to calculate indexes such as the 'Sediment Trapping Efficiency' of the herbaceous hedge

394 (Dosskey et al., 2011). The second approach performs terrain analysis through GIS use, especially on elevation dataset (Digital Elevation Model), to predict the runoff spatial patterns.

396 The elevation dataset is processed to create the flow direction and the flow accumulation. The resulting data enables to map the hydrological network used by the runoff and to delineate the watersheds or specific catchment areas of previously selected places, such as field limits or human infrastructures. Existing models focus on vegetative filter strips, based on their specific design, to evaluate the vegetation efficiency towards sediment retention. These models can be used by practitioners to evaluate the vegetation effect on soil erosion processes and runoff, at the field or the catchment scale. They are based on hydraulic roughness coefficients, such as the Manning's number $\mathrm{n}$ or the Darcy-Weisbach's coefficient $f$, and some basic plant characteristics (Govers et al., 2007). They usually focus on a limited number of plant and vegetation characteristics. The field scale-based models VFSMOD and TRAVA define the effects of the vegetative filter strips using the vegetation height and density (Deletic, 2001; Muñoz Carpena \& Parsons, 2014); while WEPP uses plant growth (aboveground and roots), height, the stem basal area and the leaf area index (Arnold et al., 1995). The catchment scale model SWAT focus on the plant height, spacing and coverage, the leaf area index and the root

410 depth (Arnold et al., 2012). Others does not integrate any plant characteristics but the 
411 Manning's hydraulic roughness coefficient (e.g. CREAMS), or the width of the vegetative filter 412 strip (e.g. LISEM) (de Roo et al., 1998; Williams \& Nicks, 1988). Results on the effects of 413 plant traits in herbaceous hedges on the hydraulic resistance and sediment retention have 414 emphasised the effects of numerous traits not used in models (e.g. stem density, stem diameter,

415 leaf area and leaf density). Implementing these traits recognised as efficient to increase the 416 hydraulic resistance and sediment retention into the models would improve the precision of the 417 model results and help better select the best implantation location. Perspective is to integrate the effects of these traits into the models at both field and catchment scales, and to validate the model predictions compared to the empirical approach.

\section{Conclusion}

This review on the effects of plant functional traits in herbaceous vegetation on the hydraulic resistance and sediment transfer has allowed the improvement of the understanding of the vegetation roles on runoff, sediment retention and erosion control, facilitating the design of herbaceous hedges for these purposes. Leaf and stem traits (i.e. leaf area, leaf density, stem diameter, stem projected area and stem density) directly increase the hydraulic resistance and sediment retention in herbaceous vegetation, especially when they are density-weighted, in temperate agricultural catchments. The knowledge of these highlighted traits to illustrate the vegetation effects on the hydraulic resistance and sediment retention is transposable to different pedoclimatic contexts, with the characterisation of the intensity of the concentrated runoff (e.g. slope and soil texture). The challenge of designing vegetation structures for soil erosion and runoff mitigation is to include the plant traits involved in the increase of the hydraulic resistance and sediment retention into the modelling of the vegetation effects by using existing models for soil erosion control. Herbaceous hedges showing dense perennial herbaceous vegetation on 
436 a narrow strip constitute a major structure to reduce concentrated flows and soil erosion under

437 temperate climates in agricultural catchments. Their design should consider (1) the selection

438 method based on the functional types and traits of the indigenous species located in the

439 implantation area; (2) the number of species and their traits composing the hedge, as choosing

440 if the hedge should comprise several species with contrasting traits and (3) the positioning of

441 the hedges using multi-scale analysis and modelling. Perspective is to unravel the contrasting

442 effects of the functional diversity on runoff and sediment retention by studying a wide gradient

443 of functional diversity within plant communities on these ecosystem processes. Comparison of

444 the functional diversity effects among several processes and services should also be examined

445 to design multifunctional ecosystems and specifically manage major ecosystem services in

446 each phytogeographical territory.

447

448

449 Acknowledgements

450 The authors thank the funders of this research project: Agence de l'Eau Seine-Normandie 451 (Seine-Normandy Catchment Agency), Région Normandie (Normandy council) and ANRT 452 (National Association for Technological Research). The authors declare that they have no conflict of interest.

\section{Data Availability Statement}

Data sharing not applicable to this article as no datasets were generated or analysed during the current study. 
References

462

463

464

465

466

467

468

469

470

471

472

473

474

475

476

477

478

479

480

481

482

483

484

485

486

487

488

489

490

491

492

493

494

495

496

497

Akram S, Yu B, Ghadiri H, Rose C, Hussein J. 2014. The links between water profile, net deposition and erosion in the design and performance of stiff grass hedges. Journal of Hydrology 510: 472-479. DOI: 10.1016/j.jhydrol.2014.01.001

Arnold JG, Kiniry JR, Williams JR, Haney EB, Neitsch SL. 2012. Soil and water assessment tool. Texas Water Resources Institute, 650

Arnold JG, Weltz MA, Alberts EE, Flanagan DC. 1995. Chapter 8. Plant growth component. USDA-Water Erosion Prediction Project Hillslope Profile and Watershed Model Documentation. NSERL

Balvanera P, Pfisterer AB, Buchmann N, He J-S, Nakashizuka T, Raffaelli D, Schmid B. 2006. Quantifying the evidence for biodiversity effects on ecosystem functioning and services: Biodiversity and ecosystem functioning/services. Ecology Letters 9: 11461156. DOI: $10.1111 /$ j.1461-0248.2006.00963.x

Bautista S, Mayor ÁG, Bourakhouadar J, Bellot J. 2007. Plant Spatial Pattern Predicts Hillslope Runoff and Erosion in a Semiarid Mediterranean Landscape. Ecosystems 10: 987-998. DOI: 10.1007/s10021-007-9074-3

Berendse F, van Ruijven J, Jongejans E, Keesstra S. 2015. Loss of plant species diversity reduces soil erosion resistance. Ecosystems. 18: 881-888. DOI: 10.1007/s10021-0159869-6

Boardman J, Poesen J (eds). 2006. Soil Erosion in Europe. John Wiley \& Sons, Ltd

Bochet E, Poesen J, Rubio JL. 2000. Mound development as an interaction of individual plants with soil, water erosion and sedimentation processes on slopes. Earth Surface Processes and Landforms 25: 847-867

Bugnon F. 1995. Nouvelle flore de Bourgogne, tome II : clés de détermination. Bulletin scientifique de Bourgogne: Dijon, France

Burylo M, Rey F, Bochet E, Dutoit T. 2012. Plant functional traits and species ability for sediment retention during concentrated flow erosion. Plant and Soil. 353: 135-144. DOI: $10.1007 / \mathrm{s} 11104-011-1017-2$

Cadotte MW. 2017. Functional traits explain ecosystem function through opposing mechanisms. Ecology Letters 20: 989-996. DOI: 10.1111/ele.12796

Cadotte MW, Carscadden K, Mirotchnick N. 2011. Beyond species: functional diversity and the maintenance of ecological processes and services. Journal of Applied Ecology 48: 1079-1087. DOI: 10.1111/j.1365-2664.2011.02048.x

Cantalice JRB, Melo RO, Silva YJAB, Cunha Filho M, Araújo AM, Vieira LP, Bezerra SA, Barros G, Singh VP. 2015. Hydraulic roughness due to submerged, emergent and flexible natural vegetation in a semiarid alluvial channel. Journal of Arid Environments 114: 1-7. DOI: 10.1016/j.jaridenv.2014.10.012 
Cao L, Zhang Y, Lu H, Yuan J, Zhu Y, Liang Y. 2015. Grass hedge effects on controlling soil loss from concentrated flow: A case study in the red soil region of China. Soil and Tillage Research 148: 97-105. DOI: 10.1016/j.still.2014.12.009

Cao S. 2011. Impact of China's Large-Scale Ecological Restoration Program on the Environment and Society in Arid and Semiarid Areas of China: Achievements, Problems, Synthesis, and Applications. Critical Reviews in Environmental Science and Technology 41: 317-335. DOI: 10.1080/10643380902800034

Cao S, Chen L, Yu X. 2009. Impact of China's Grain for Green Project on the landscape of vulnerable arid and semi-arid agricultural regions: a case study in northern Shaanxi Province. Journal of Applied Ecology 46: 536-543. DOI: 10.1111/j.13652664.2008.01605.x

Carluer N, Lauvernet C, Noll D, Munoz-Carpena R. 2017. Defining context-specific scenarios to design vegetated buffer zones that limit pesticide transfer via surface runoff. Science of the Total Environment 575: 701-712. DOI: 10.1016/j.scitotenv.2016.09.105

Cullum RF, Wilson GV, McGregor KC, Johnson JR. 2007. Runoff and soil loss from ultranarrow row cotton plots with and without stiff-grass hedges. Soil and Tillage Research 93: 56-63

Dabney SM, Meyer LD, Harmon WC, Alonso CV, Foster GR. 1995. Depositional patterns of sediment trapped by grass hedges. Transactions of the ASAE. 38: 1719-1729

Dabney SM, Shields Jr FD, Temple DM, Langendoen EJ. 2004. Erosion processes in gullies modified by establishing grass hedges. Transactions of the ASAE 47: 1561

De Baets S, Poesen J, Gyssels G, Knapen A. 2006. Effects of grass roots on the erodibility of topsoils during concentrated flow. Geomorphology. 76: 54-67. DOI: 10.1016/j.geomorph.2005.10.002

De Baets S, Poesen J, Reubens B, Muys B, De Baerdemaeker J, Meersmans J. 2009. Methodological framework to select plant species for controlling rill and gully erosion: application to a Mediterranean ecosystem. Earth Surface Processes and Landforms 34: 1374-1392. DOI: 10.1002/esp.1826

de Roo A, Jetten V, Wesseling C, Ritsema C. 1998. LISEM: A Physically-Based Hydrologic and Soil Erosion Catchment Model. In: Boardman J and Favis-Mortlock D (eds) Modelling Soil Erosion by Water. Springer: Berlin, Heidelberg, 429-440. DOI: 10.1007/978-3-642-58913-3_32

Deletic A. 2001. Modelling of water and sediment transport over grassed areas. Journal of Hydrology 248: 168-182. DOI: 10.1016/S0022-1694(01)00403-6

Díaz S, Lavorel S, Chapin FS, Tecco PA, Gurvich DE, Grigulis K. 2007a. Functional Diversity - at the Crossroads between Ecosystem Functioning and Environmental Filters. In: Canadell JG, Pataki DE and Pitelka LF (eds) Terrestrial Ecosystems in a Changing World. Springer Berlin Heidelberg: Berlin, Heidelberg, 81-91. DOI: 10.1007/978-3-540-32730-1_7 
Díaz S, Lavorel S, de Bello F, Quetier F, Grigulis K, Robson TM. 2007b. Incorporating plant functional diversity effects in ecosystem service assessments. Proceedings of the National Academy of Sciences 104: 20684-20689. DOI: 10.1073/pnas.0704716104

Dillaha TA, Reneau RB, Mostaghimi S, Lee D. 1989. Vegetative filter strips for agricultural nonpoint source pollution control. Transactions of the ASAE 32: 513-0519

Doak DF, Bigger D, Harding EK, Marvier MA, O’Malley RE, Thomson D. 1998. The Statistical Inevitability of Stability-Diversity Relationships in Community Ecology. The American Naturalist 151: 264-276. DOI: 10.1086/286117

Dosskey MG, Neelakantan S, Mueller TG, Kellerman T, Helmers MJ, Rienzi E. 2015. AgBufferBuilder: A geographic information system (GIS) tool for precision design and performance assessment of filter strips. Journal of Soil and Water Conservation 70: $209-217$. DOI: $10.2489 /$ jswc.70.4.209

Dosskey MG, Qiu Z, Helmers MJ, Eisenhauer DE. 2011. Improved indexes for targeting placement of buffers of Hortonian runoff. Journal of Soil and Water Conservation 66: 362-372. DOI: $10.2489 /$ jswc.66.6.362

Dosskey MG, Vidon P, Gurwick NP, Allan CJ, Duval TP, Lowrance R. 2010. The role of riparian vegetation in protecting and improving chemical water quality in streams. Journal of the American water resources association 1-18. DOI: 10.1111/j.17521688.2010.00419.x

Durán Zuazo VH, Rodríguez Pleguezuelo CR. 2008. Soil-erosion and runoff prevention by plant covers. A review. Agronomy for Sustainable Development 28: 65-86. DOI: 10.1051/agro:2007062

Erktan A, Cécillon L, Roose E, Frascaria-Lacoste N, Rey F. 2013. Morphological diversity of plant barriers does not increase sediment retention in eroded marly gullies under ecological restoration. Plant and Soil 370: 653-669. DOI: 10.1007/s11104-013-17385

Faucon M-P, Houben D, Lambers H. 2017. Plant functional traits: soil and ecosystem services. Trends in Plant Science 22: 385-394. DOI: 10.1016/j.tplants.2017.01.005

Flanagan DC, Ascough JC, Nearing MA, Laflen JM. 2001. The Water Erosion Prediction Project (WEPP) Model. In: Harmon RS and Doe WW (eds) Landscape Erosion and Evolution Modeling. Springer US: Boston, MA, 145-199. DOI: 10.1007/978-1-46150575-4_7

Fullen MA. 1998. Effects of grass ley set-aside on runoff, erosion and organic matter levels in sandy soils in east Shropshire, UK. Soil \& Tillage Research 46: 41-49

Garnier E, Cortez J, Billès G, Navas M-L, Roumet C, Debussche M, Laurent G, Blanchard A, Aubry D, Bellmann A, Neill C, Toussaint J-P. 2004. Plant functional markers capture ecosystem properties during secondary succession. Ecology 85: 2630-2637. DOI: 10.1890/03-0799 
Garnier E, Navas M-L. 2012. A trait-based approach to comparative functional plant ecology: concepts, methods and applications for agroecology. A review. Agronomy for Sustainable Development 32: 365-399

Garnier E, Navas M-L, Grigulis K. 2016. Plant Functional Diversity: Organism Traits, Community Structure, and Ecosystem Properties. Oxford University Press

Gilley JE, Eghball B, Kramer LA, Moorman TB. 2000. Narrow grass hedge effects on runoff and soil loss. Journal of Soil and Water Conservation 55: 190-196

Gilley JE, Kottwitz ER. 1995. Darcy-Weisbach roughness coefficients for surfaces with residue and gravel cover. Transactions of the ASAE 38: 539-544

Gobin A, Govers G, Jones R, Kirkby M, Kosmas C, Gentile AR. 2003. Assessment and reporting on soil erosion: Background and workshop report. Technical. European Environment Agency: Copenhagen

Govers G. 1990. Empirical relationships for the transport capacity of overland flow. International Association of Hydrological Sciences 189: 45-63

Govers G, Giménez R, Van Oost K. 2007. Rill erosion: Exploring the relationship between experiments, modelling and field observations. Earth-Science Reviews 84: 87-102. DOI: $10.1016 /$ j.earscirev.2007.06.001

Graff CD, Sadeghi AM, Lowrance RR, Williams RG. 2005. Quantifying the sensitivity of the riparian ecosystem management model (REMM) to changes in climate and buffer characteristics common to conservation practices. Transactions of the ASAE $\mathbf{4 8}$ : 1377-1387

Grime JP. 1998. Benefits of plant diversity to ecosystems: immediate, filter and founder effects. Journal of ecology 86: 902-910. DOI: 10.1046/j.1365-2745.1998.00306.x

Gumiere SJ, Bissonnais YL, Raclot D, Cheviron B. 2011. Vegetated filter effects on sedimentological connectivity of agricultural catchments in erosion modelling: a review. Earth Surface Processes and Landforms 36: 3-19. DOI: 10.1002/esp.2042

Gyssels G, Poesen J, Bochet E, Li Y. 2005. Impact of plant roots on the resistance of soils to erosion by water: A review. Progress in Physical Geography 29: 189-217. DOI: 10.1191/0309133305pp443ra

Haan CT, Barfield BJ, Hayes JC. 1994. Design Hydrology and Sedimentology for Small Catchments. Academic Press

Hayes JC, Barfield BJ, Barnhisel RI. 1984. Performance of grass filters under laboratory and field conditions. Transactions of the ASAE 27: 1321-1331

Hegi G. 1906. Illustrierte Flora von Mitteleuropa. Band I - VI. Lehmanns Verlag München: Munich, Germany

Hou J, Wang H, Fu B, Zhu L, Wang Y, Li Z. 2016. Effects of plant diversity on soil erosion for different vegetation patterns. CATENA 147: 632-637. DOI: 10.1016/j.catena.2016.08.019 
Huang D, Han JG, Wu JY, Wang K, Wu WL, Teng WJ, Sardo V. 2010. Grass hedges for the protection of sloping lands from runoff and soil loss: An example from Northern China. Soil and Tillage Research 110: 251-256. DOI: 10.1016/j.still.2010.08.013

Hussein J, Yu B, Ghadiri H, Rose C. 2007. Prediction of surface flow hydrology and sediment retention upslope of a vetiver buffer strip. Journal of Hydrology 338: 261272

Isselin-Nondedeu F, Bédécarrats A. 2007. Influence of alpine plants growing on steep slopes on sediment trapping and transport by runoff. Catena. 71: 330-339. DOI: 10.1016/j.catena.2007.02.001

Jauzein P, Nawrot O. 2011. Flore d'Ile-de-France. QUAE: Versailles, France

Kervroëdan L, Armand R, Saunier M, Faucon M-P. 2019. Effects of plant traits and their divergence on runoff and sediment retention in herbaceous vegetation. Plant and Soil 441: 511-524. DOI: 10.1007/s11104-019-04142-6

Kervroëdan L, Armand R, Saunier M, Ouvry J-F, Faucon M-P. 2018. Plant functional trait effects on runoff to design herbaceous hedges for soil erosion control. Ecological Engineering 118: 143-151. DOI: 10.1016/j.ecoleng.2018.04.024

Knisel WG, Nicks AD. 1980. CREAMS: A Field Scale Model for Chemicals, Runoff, and Erosion from Agricultural Management Systems. Conservation Research Report. U.S. Department of Agriculture, Science and Education Administration, 640

Lambinon J, Delvosalle L, Duvigneaud J. 2012. Nouvelle flore de la Belgique, du G.-D. de Luxembourg, du nord de la France et des régions voisines.

Lambrechts T, François S, Lutts S, Muñoz-Carpena R, Bielders CL. 2014. Impact of plant growth and morphology and of sediment concentration on sediment retention efficiency of vegetative filter strips: Flume experiments and VFSMOD modeling. Journal of Hydrology 511: 800-810. DOI: 10.1016/j.jhydrol.2014.02.030

Lin C, Tu S, Huang J, Chen Y. 2009. The effect of plant hedgerows on the spatial distribution of soil erosion and soil fertility on sloping farmland in the purple-soil area of China. Soil and Tillage Research 105: 307-312. DOI: 10.1016/j.still.2009.01.001

Liu H, Yao L, Lin C, Wang X, Xu W, Wang H. 2018a. 18-year grass hedge effect on soil water loss and soil productivity on sloping cropland. Soil and Tillage Research 177: 12-18. DOI: 10.1016/j.still.2017.11.007

Liu J, Gao G, Wang S, Jiao L, Wu X, Fu B. 2018b. The effects of vegetation on runoff and soil loss: Multidimensional structure analysis and scale characteristics. Journal of Geographical Sciences 28: 59-78. DOI: 10.1007/s11442-018-1459-Z

Liu Y-F, Dunkerley D, López-Vicente M, Shi Z-H, Wu G-L. 2020. Trade-off between surface runoff and soil erosion during the implementation of ecological restoration programs in semiarid regions: A meta-analysis. Science of The Total Environment 712: 136477 . DOI: $10.1016 /$ j.scitotenv.2019.136477 
Ludwig JA, Wilcox BP, Breshears DD, Tongway DJ, Imeson AC. 2005. Vegetation patches and runoff-erosion as interacting ecohydrological processes in semiarid landscapes. Ecology. 86: 288-297. DOI: 10.1890/03-0569

Mansion D, Dume G, Rameau JC. 1989. Flore Forestière Française : Guide Ecologique Illustré. Institut pour le développement forestier: Paris

Mariotte P, Mehrabi Z, Bezemer TM, De Deyn GB, Kulmatiski A, Drigo B, Veen GC, van der Heijden MG, Kardol P. 2017. Plant-Soil Feedback: Bridging Natural and Agricultural Sciences. Trends in ecology \& evolution

Martin C, Pohl M, Alewell C, Körner C, Rixen C. 2010. Interrill erosion at disturbed alpine sites: Effects of plant functional diversity and vegetation cover. Basic and Applied Ecology 11: 619-626. DOI: 10.1016/j.baae.2010.04.006

Maun MA. 1998. Adaptations of plants to burial in coastal sand dunes. 76: 26

Mekonnen M, Keesstra SD, Ritsema CJ, Stroosnijder L, Baartman JEM. 2016. Sediment trapping with indigenous grass species showing differences in plant traits in northwest Ethiopia. Catena 147: 755-763. DOI: 10.1016/j.catena.2016.08.036

Mekonnen M, Keesstra SD, Stroosnijder L, Baartman JEM, Maroulis J. 2015. Soil Conservation Through Sediment Trapping: A Review. Land Degradation \& Development 26: 544-556. DOI: $10.1002 / \mathrm{ldr} .2308$

Meyer LD, Dabney SM, Harmon WC. 1995. Sediment-trapping effectiveness of stiff-grass hedges. American Society of Agricultural Engineers 38: 809-815

Morgan RPC. 2004. Vegetative-Based Technologies for Erosion Control. In: Stokes A, Spanos I, Norris JE and Cammeraat E (eds) Eco- and Ground Bio-Engineering: The Use of Vegetation to Improve Slope Stability. Springer: Dordrecht, The Netherlands, 265-272

Morgan RPC. 2009. Soil Erosion and Conservation. John Wiley \& Sons

Morgan RPC, Duzant JH. 2008. Modified MMF (Morgan-Morgan-Finney) model for evaluating effects of crops and vegetation cover on soil erosion. Earth Surface Processes and Landforms 33: 90-106. DOI: 10.1002/esp.1530

Mouillot D, Villéger S, Scherer-Lorenzen M, Mason NWH. 2011. Functional Structure of Biological Communities Predicts Ecosystem Multifunctionality. PLoS ONE 6: e17476. DOI: 10.1371/journal.pone.0017476

Muñoz Carpena R, Parsons JE. 2014. VFSMOD - Vegetative filter strips modelling system. Model documentation and user's manual. University of Florida, 176

Podwojewski P, Janeau JL, Grellier S, Valentin C, Lorentz S, Chaplot V. 2011. Influence of grass soil cover on water runoff and soil detachment under rainfall simulation in a sub-humid South African degraded rangeland. Earth Surface Processes and Landforms 36: 911-922. DOI: 10.1002/esp.2121 
Poesen J. 2018. Soil erosion in the Anthropocene: Research needs. Earth Surface Processes and Landforms 43: 64-84. DOI: 10.1002/esp.4250

Pohl M, Alig D, Körner C, Rixen C. 2009. Higher plant diversity enhances soil stability in disturbed alpine ecosystems. Plant and Soil 324: 91-102. DOI: 10.1007/s11104-0099906-3

Puigdefábregas J. 2005. The role of vegetation patterns in structuring runoff and sediment fluxes in drylands. Earth Surface Processes and Landforms 30: 133-147. DOI: 10.1002/esp. 1181

Remy J-C, Le Bissonnais Y. 1998. Comparaison des phénomènes d'érosion entre le nord et le sud de l'Europe: ampleur des problèmes et nature des mécanismes. Bulletin réseau érosion. IRD: Montpellier

Renschler C, Flanagan D, Engel B, Frankenberger J. 2002. GeoWEPP-The Geo-spatial interface for the Water Erosion Prediction Project. . DOI: 10.13031/2013.10418

Rey F, Labonne S. 2015. Resprout and survival of willow (Salix) cuttings on bioengineering structures in actively eroding gullies in marls in a mountainous Mediterranean climate: A large-scale experiment in the Francon catchment (southern Alps, France). Environmental Management 56: 971-983. DOI: 10.1007/s00267-015-0542-9

Richet J-B, Ouvry J-F, Saunier M. 2017. The role of vegetative barriers such as fascines and dense shrub hedges in catchment management to reduce runoff and erosion effects: Experimental evidence of efficiency, and conditions of use. Ecological Engineering 103: 455-469. DOI: 10.1016/j.ecoleng.2016.08.008

Rothmaler W, Jäger EJ. 2009. Rothmaler - Exkursionsflora von Deutschland. Bd. 3: Gefäßpflanzen: Atlasband. Sperktrum Akademischer Verlag: Berlin, Germany

Stokes A (ed). 2007. Eco- and ground bio-engineering: the use of vegetation to improve slope stability: proceedings of the First International Conference on EcoEngineering, 13-17 September 2004. Springer: Dordrecht

Stokes A, Douglas GB, Fourcaud T, Giadrossich F, Gillies C, Hubble T, Kim JH, Loades KW, Mao Z, McIvor IR, Mickovski SB, Mitchell S, Osman N, Phillips C, Poesen J, Polster D, Preti F, Raymond P, Rey F, Schwarz M, Walker LR. 2014. Ecological mitigation of hillslope instability: ten key issues facing researchers and practitioners. Plant and Soil. 377: 1-23. DOI: 10.1007/s11104-014-2044-6

Styczen ME, Morgan RPC. 1995. Engineering properties of vegetation. In: Morgan RPC and Rickson RJ (eds) Slope Stabilization and Erosion Control: A Bioengineering Approach. E \& FN SPON: London, 4-60

Temple DM, Robinson KM, Ahring RM, Davis AG. 1987. Stability Design of Grass-Lined Open Channels. U.S. Department of Agriculture: Washington, D.C.

Tilman D. 1999. The ecological consequences of changes in biodiversity: A search for general principles. Ecology 80: 1455-1474. DOI: 10.1890/00129658(1999)080[1455:TECOCI $] 2.0 . \mathrm{CO} ; 2$ 
Tilman D. 2001. Functional Diversity. In: Levin SA (ed) Encyclopedia of Biodiversity. Elsevier: New York, 109-120. DOI: 10.1016/B0-12-226865-2/00132-2

Tilman D, Isbell F, Cowles JM. 2014. Biodiversity and Ecosystem Functioning. Annual Review of Ecology, Evolution, and Systematics 45: 471-493. DOI: 10.1146/annurevecolsys-120213-091917

Tomer MD, Dosskey MG, Burkart MR, James DE, Helmers MJ, Eisenhauer DE. 2008. Methods to prioritize placement of riparian buffers for improved water quality. Agroforest Syst: 10 p.

Turnbull L, Wainwright J, Brazier RE. 2008. A conceptual framework for understanding semi-arid land degradation: ecohydrological interactions across multiple-space and time scales. Ecohydrology 1: 23-34. DOI: 10.1002/eco.4

Université de Bourgogne (UFR Science de la vie). 2018. Nouvelle Flore de Bourgogne Tome II Clés de détermination. Flore de Bourgogne

Van Dijk PM, Kwaad FJPM, Klapwijk M. 1996. Retention of water and sediment by grass strips. Hydrological Processes 10: 1069-1080. DOI: 10.1002/(SICI)10991085(199608)10:8<1069::AID-HYP412>3.0.CO;2-4

Vandaele K, Poesen J. 1995. Spatial and temporal patterns of soil erosion rates in an agricultural catchment, central Belgium. CATENA 25: 213-226. DOI: 10.1016/03418162(95)00011-G

Vannoppen W, Vanmaercke M, De Baets S, Poesen J. 2015. A review of the mechanical effects of plant roots on concentrated flow erosion rates. Earth-Science Reviews 150: 666-678. DOI: 10.1016/j.earscirev.2015.08.011

Vieira DAN, Dabney SM. 2012. Two-dimensional flow patterns near contour grass hedges. Hydrological Processes 26: 2225-2234. DOI: 10.1002/hyp.8262

Villarroel B. 2015. Influence des traits morphologiques des végétaux herbacés sur l'érosion et le ruissellement des sols cultivés du nord-ouest de l'Europe. MSc Thesis, AgoParisTech

Violle C, Navas M-L, Vile D, Kazakou E, Fortunel C, Hummel I, Garnier E. 2007. Let the concept of trait be functional! Oikos 116: 882-892. DOI: 10.1111/j.2007.00301299.15559.x

Williams RD, Nicks AD. 1988. Using CREAMS to simulate filter strip effectiveness in erosion control. Journal of Soil and Water Conservation 43: 108-112

Wu JY, Huang D, Teng WJ, Sardo VI. 2010. Grass hedges to reduce overland flow and soil erosion. Agronomy for Sustainable Development 30: 481-485. DOI: 10.1051/agro/2009037

Xiao B, Wang Q, Wang H, Wu J, Yu D. 2012. The effects of grass hedges and micro-basins on reducing soil and water loss in temperate regions: A case study of Northern China. Soil and Tillage Research 122: 22-35. DOI: 10.1016/j.still.2012.02.006 
Yuan Y, Bingner RL, Locke MA. 2009. A Review of effectiveness of vegetative buffers on sediment trapping in agricultural areas. Ecohydrology 2: 321-336. DOI: $10.1002 /$ eco. 82

769

770

771

772

773

774

775

779

Zhang L, Wang J, Bai Z, Lv C. 2015. Effects of vegetation on runoff and soil erosion on reclaimed land in an opencast coal-mine dump in a loess area. CATENA 128: 44-53. DOI: $10.1016 /$ j.catena.2015.01.016

Zhu H, Fu B, Wang S, Zhu L, Zhang L, Jiao L, Wang C. 2015. Reducing soil erosion by improving community functional diversity in semi-arid grasslands. Journal of Applied Ecology 52: 1063-1072. DOI: 10.1111/1365-2664.12442

Zuo X, Zhang J, Lv P, Zhou X, Li Y, Luo Y, Luo Y, Lian J, Yue X. 2016. Plant functional diversity mediates the effects of vegetation and soil properties on community-level plant nitrogen use in the restoration of semiarid sandy grassland. Ecological Indicators 64: 272-280. DOI: 10.1016/j.ecolind.2016.01.012 


\section{west European loess belt.}

783 The minimum vegetative heights are represented under the median value (Quartile 1; Quartile

784 4) of the data obtained from Hegi (1906); Jauzein and Nawrot (2011); Lambinon et al. (2012);

785 Mansion et al. (1989); Rothmaler and Jäger (2009); Bugnon (1995) In Université de Bourgogne

786 (UFR Science de la vie) (2018)). Hem.: Hemicryptophyte; C. Hem.: Caespitose

787 hemicryptophyte; Ch.: Chamaephyte; R. Hem: Rosette hemicryptophyte.

\begin{tabular}{|c|c|c|c|}
\hline Family & Species name & Life form & $\begin{array}{c}\text { Minimum } \\
\text { vegetative height } \\
(\mathrm{cm})\end{array}$ \\
\hline Adoxaceae & Sambucus ebulus $L$. & Hem. & $55(50 ; 80)$ \\
\hline \multirow{3}{*}{ Apiaceae } & Anthriscus sylvestris (L.) Hoffmann & Hem. & $45(40 ; 80)$ \\
\hline & Bupleurum falcatum $L$. & Hem. & $30(20 ; 50)$ \\
\hline & Heracleum sphondylium L. & Hem. & $50(30 ; 50)$ \\
\hline \multirow{11}{*}{ Asteraceae } & Achillea ptarmica $L$. & Hem. & $20(20 ; 30)$ \\
\hline & Artemisia verlotiorum & Hem. & $70(67.5 ; 150)$ \\
\hline & Artemisia vulgaris $L$. & Hem. & $60(52.5 ; 60)$ \\
\hline & Aster laevis L. & Hem. & $60(60 ; 60)$ \\
\hline & Aster salignus Willd. & Hem. & $80(72.5 ; 90)$ \\
\hline & Eupatorium cannabinum L. & Hem. & $55(50 ; 80)$ \\
\hline & Hieracium piloselloides Vill. & Hem. & $20(20 ; 20)$ \\
\hline & Senecio jacobaea $L$. & Hem. & $30(30 ; 40)$ \\
\hline & Tanacetum corymbosum $L$. & Hem. & $30(30 ; 50)$ \\
\hline & Tanacetum parthenium L. & Hem. & $30(30 ; 30)$ \\
\hline & Tanacetum vulgare $L$. & Hem. & $55(42.5 ; 60)$ \\
\hline Caryophyllaceae & Saponaria officinalis $L$. & Hem. & $30(30 ; 30)$ \\
\hline Clusiaceae & Hypericum perforatum $L$. & Hem. & $27.5(21.25 ; 30)$ \\
\hline \multirow{10}{*}{ Cyperaceae } & Carex acutiformis Ehrh. & Hem. & $50(35 ; 50)$ \\
\hline & Carex binervis Smith & C. Hem. & $30(30 ; 30)$ \\
\hline & Carex brizoides $L$. & Hem. & $25(25 ; 30)$ \\
\hline & Carex canescens $L$. & Hem. & $20(20 ; 25)$ \\
\hline & Carex otrubae Podp. & Hem. & $30(30 ; 30)$ \\
\hline & Carex diandra Schrank & Hem. & $20(20 ; 30)$ \\
\hline & Carex distans $L$. & Hem. & $22.5(20 ; 30)$ \\
\hline & Carex divulsa Stokes & C. Hem. & $20(20 ; 30)$ \\
\hline & Carex elongata $L$. & C. Hem. & $30(30 ; 30)$ \\
\hline & Carex flacca Schreb. & Hem. & $20(10 ; 20)$ \\
\hline
\end{tabular}




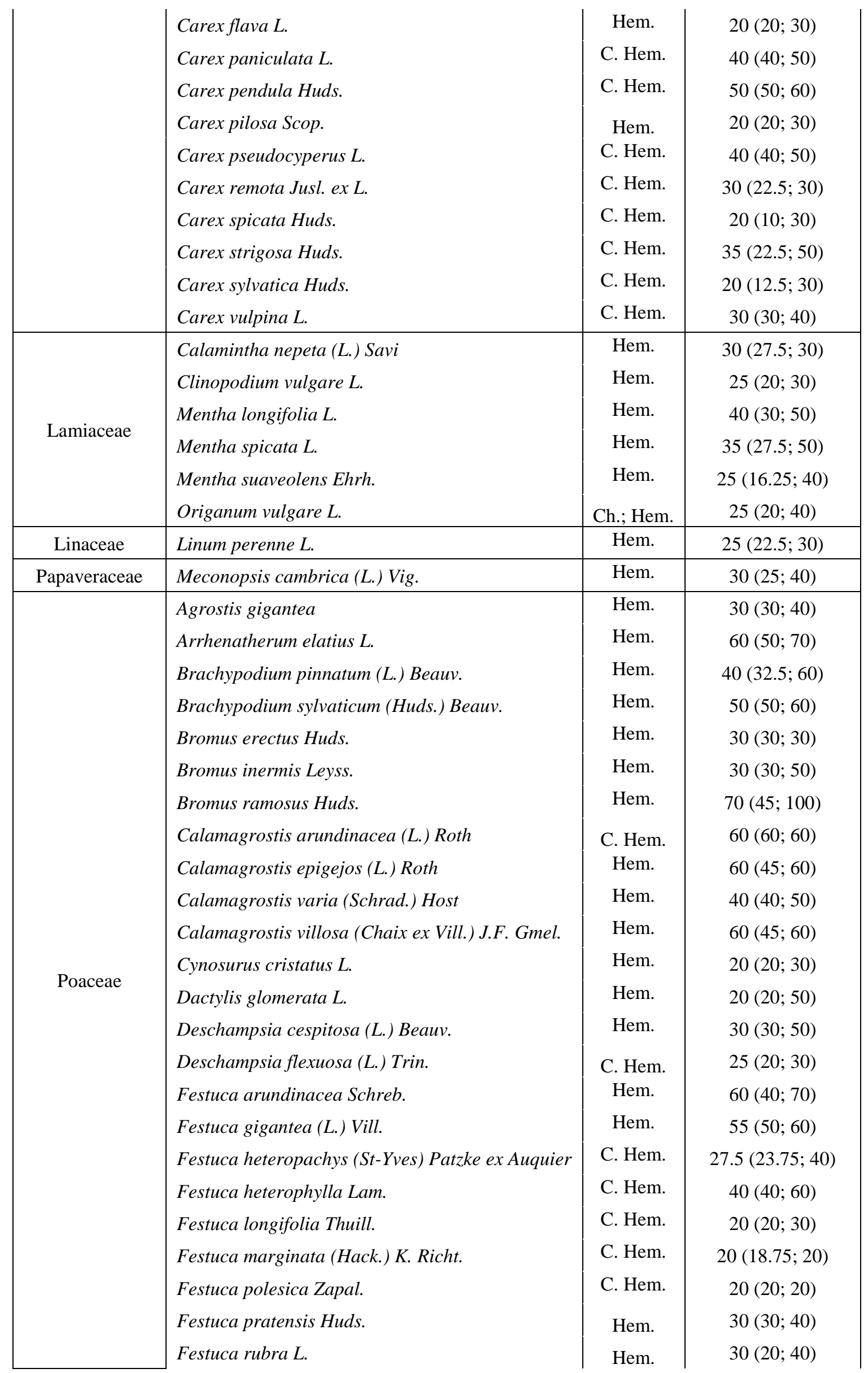




\begin{tabular}{|l|l|c|c|} 
& Koeleria pyramidata (Lam.) Beauv. & Hem. & $20(20 ; 45)$ \\
& Melica ciliata L. & Hem. & $22.5(20 ; 30)$ \\
& Melica nutans L. & Hem. & $30(22.5 ; 30)$ \\
& Melica uniflora Retz. & Hem. & $25(20 ; 30)$ \\
& Milium effusum L. & Hem. & $55(50 ; 80)$ \\
& Phalaris arundinacea L. & Hem. & $50(50 ; 80)$ \\
\hline Rosaceae & Filipendula ulmaria $($ L.) Maxim. & R. Hem. & $50(50 ; 100)$ \\
\hline
\end{tabular}



weighted trait on the hydraulic resistance and sediment retention.

792 The threshold values were identified using the results from the generalised linear regression

793 models in Kervroëdan et al. (2018). It represents the intersection between the USP critical value

794 and the regression curve. As leaf area and density had different responses toward the hydraulic

795 resistance depending on the discharge, the non-significant effects for the relevant discharges

796 were darkened. The combination of both leaf area and leaf density was found to explain better

797 the effects on the hydraulic resistance for all discharges rather than the traits taken separately.

\begin{tabular}{|l|c|c|c|c|}
\cline { 2 - 5 } \multicolumn{1}{c|}{} & $2 \mathrm{~L} \cdot \mathrm{s}^{-1} \cdot \mathrm{m}^{-1}$ & $4 \mathrm{~L} \cdot \mathrm{s}^{-1} \cdot \mathrm{m}^{-1}$ & $8 \mathrm{~L} \cdot \mathrm{s}^{-1} \cdot \mathrm{m}^{-1}$ & $11 \mathrm{~L} \cdot \mathrm{s}^{-1} \cdot \mathrm{m}^{-1}$ \\
\hline Leaf area $\left(\mathrm{mm}^{2}\right)$ & 200 & 2200 & 6500 & 8200 \\
Leaf density $\left(\mathrm{m}^{-2}\right)$ & 0 & 7000 & 25000 & 31000 \\
W. leaf area $\left(\mathrm{mm}^{2} \cdot \mathrm{m}^{-2}\right)$ & 200000 & 22750000 & 82000000 & 100000000 \\
W. projected stem area $\left(\mathrm{mm}^{2} \cdot \mathrm{m}^{-2}\right)$ & 200000 & 840000 & 1875000 & 2350000 \\
W. stem diameter $\left(\mathrm{mm} \cdot \mathrm{m}^{-2}\right)$ & 2000 & 8000 & 19000 & 23000 \\
\hline
\end{tabular}

